Editorials

16 On the Retirement of

Prof. Dr. Dr. h.c. mult. Reinhard Bittner

Klar, E. (Rostock); Mössner, J. (Leipzig)

18 Esophageal Cancer - Something Is Happening!

Ell, C. (Wiesbaden); Hölscher, A. (Köln)

283 Complications and Complication Management in the Gastrointestinal Tract

Heidecke, C.-D.; Lerch, M.M. (Greifswald)

3191 Liver Metastases

Lippert, H. (Magdeburg); Mössner, J. (Leipzig); Ricke, J. (Magdeburg)

4270 Minimum Case Loads in Surgery

Jost, J.O. (Bielefeld); Klar, E. (Rostock)

Obituary

282 Steven Karger (1959-2008)

3254 Obituary Dr. Dr. Herbert Falk Vetter, C. (Köln)

Main Topic

Esophageal Cancer - Something Is Happening!

Editors: C. Ell, Wiesbaden; A.H. Hölscher, Köln

19 Limited and Minimally Invasive Operations

in Esophageal Cancer

Lorenz, D.; Origer, J.; Graupe, F. (Wiesbaden)

116 Endoscopic and Endosonographic Diagnostics Pech, O.; Ell, C. (Wiesbaden)

123 Endoscopic Resection and Ablation in Esophageal Cancer Manner, H.; Pech, O.; Ell, C. (Wiesbaden)

134 Palliative Treatment of Esophageal Cancer May, A. (Wiesbaden)
Complications and Complication Management in the Gastrointestinal Tract

Editors: C.-D. Heidecke, M.M. Lerch, Greifswald

284 Therapy of Complications Following Esophagectomy Westerholt, A.; Maier, S. (Greifswald); Bartels, H. (München); Heidecke, C.-D.; Glitsch, A. (Greifswald)

292 Management of Postoperative Complications after Gastric Resections Sendler, A.; Bergmann, U.; Henning, B.; Jonas, S. (Herne)

299 Endoscopic Complications and Endoscopic Complication Management in Cardia and Stomach Kraft, M.; Mayerle, J.; Simon, P.; Aghdassi, A.; Lerch, M.M. (Greifswald)

2103 Etiopathogenesis and Prevention of Iatrogenic Pancreatitis

Ringel, J.; Wahnschaffe, U.; Lerch, M.M. (Greifswald)

2108 Management of Postoperative Complications in Pancreatic Surgery

Kutup, A.; Yekebas, E.F.; Izbicki, J.R. (Hamburg)

2115 Management of Postoperative and Postinterventional Bile Duct Complications Mihaljevic, A.L.; Kleeff, J.; Friess, H. (München)

2124 Complication Management after Liver Surgery and Liver Transplantation Brockmann, J.; Vogel, T.; Senninger, N. (Münster)

2134 Management of Leakages and Complications Following Extraperitoneal Rectal Anastomoses Glitsch, A.; Schreiber, A.; Seltrecht, U.; Partecke, I.; Paul, H.; Patrzyk, M.; Heidecke, C.-D.; von Bernsdorff, W. (Greifswald)

2142 Management of Postoperative Complications Following Colonic Resections Kujath, P.; Hofmann, M.; Shekarriz, H. (Lübeck)

\section{Liver Metastases}

Editors: H. Lippert, Magdeburg; J. Mössner, Leipzig; J. Ricke, Magdeburg

3192 Current Standard of Surgical Treatment in Colorectal Liver Metastases

Grundmann, R.T. (Burghausen)

3200 Interventional, Nonsurgical Treatment of Liver Metastases

Weis, S.; Tröltzsch, M.; Mössner, J. (Leipzig)

3207 Minimally Invasive Oncology in the Treatment of Liver Metastases Seidensticker, M.; Ricke, J. (Magdeburg)

\section{KARGER}

Fax +49 7614520714

Information@Karger.de

www.karger.com
() 2008 S. Karger GmbH, Freiburg 


\section{Minimum Case Loads in Visceral Medicine}

Editors: E. Klar, Rostock; J.O. Jost, Bielefeld

4271 Volume Thresholds for Hospitals in Germany Hermanek, P.; Burmeister, C. (München)

4274 Minimum Case Loads in Visceral Surgery - What Is Crucial: The Surgical Center or the Single Surgeon? Bollschweiler, E.; Metzger, R.; Vallböhmer, D.; Hölscher, A.H. (Köln)

4281 Hospital Volume and Outcome: Is One Parameter Sufficient for Assessment?

Ohmann, C; Blum, K.; de Cruppé, W.; Geraedts, M (Düsseldorf)

4288 Does the Introduction of Minimum Case Loads Has Any Implications for the Further Education in Visceral Surgery? If Yes, Which Ones and How to Respond? Rückert, K. (Hamburg)

4293 Correlations between Short-Term Post-Operative and Long-Term Oncologic Results after Rectum Carcinoma Resections and Hospital Volume? Kube, R. (Magdeburg); Ptok, H. (Mageburg/Cottbus); Schmidt, U.; Mroczkowski, P. (Magdeburg); Gastinger, I. (Mageburg); Lippert, H. (Magdeburg); für die Studiengruppe «Qualitätssicherung, (Rektumkarzinome (Primärtumor)»)

Continuing Medical Education

2146 Stadium-Adjusted Diagnostics and Treatment of Acute Diverticulitis of the Colon sigmoideum Schreiber, A.; Heidecke, C.-D.; Glitsch, A. (Greifswald)

Interdisciplinary Discussion

140 Esophageal Carcinoma

Heidecke, C.-D. (Diskussionsleiter) (Greifswald)

4400 Minimum Case Loads in General and Gastrointestinal Surgery

Jost, J.O. (Bielefeld) (Gesprächsleiter)

Original Articles

145 Prevalence of Obesity and the First Experience of Laparoscopic Adjustable Gastric Banding in Lithuania

Brimas, G.; Barzda, A.; Lipnickas, V.; Valiukenas, V.; Brimine, V.; Strupas, K. (Vilnius)

151 Recurrence after Liver Resection for Hepatocellular Carcinoma in Cirrhotic and Noncirrhotic Patients

Lanthaler, M.; Biebl, M.; Weissenbacher, A.; Margreiter, R.; Nehoda, H. (Innsbruck)
2156 Diagnosis and Therapy of Gastroesophageal Reflux - Results of a German Nationwide Survey Hartmann, J.; Nocon, M.; Naumann, H.; Hartmann, H.; Ordemann, J. (Berlin); Jacobi, C.A. (Wesseling)

2162 Results of Ethyl Pyruvate Application in an Experimental Colitis Model Karabeyoğlu, Ş.M.; Bozkurt, B.; Ünal, B.; Yilmaz, O.C.; Bilgihan, A.; Öz Atasay, F.; Üstün, H.; Cengiz, Ö. (Ankara)

2167 Open versus Laparoscopic Management of Gastroduodenal Ulcer Perforation: A SingleInstitution Comparative Experience Li, B.; Yu, H.; Liu, J.; Yu, W.; Wang, F.; Chen, B.; Hu, S. (Jinan)

3216 Should We Perform Polypectomy for All Colorectal Polyps or Follow-up? Öztürk, Z.A.; Köklü, S.; Basat, O.; Yüksel, O.; Filik, L. (Ankara)

3221 Lumbar Hernia: Clinical Analysis of Cases and Review of the Literature Hu, S.-D.; Shen, K.-L.; Liu, H.-D.; Chen, T.-W.; Yu, J.-C. (Taipei)

3226 Complications by Immunosuppressive Therapy after Liver Transplantation - a Retrospective 12-Year Analysis of the Transplant Center Bonn Stoffels, B.; Tolba, R.H.; Schildberg, F.A. (Bonn); Wolff, M. (Hanau); Kalff, J.C.; Hirner, A. (Bonn)

3234 Evaluation of Clinical Parameters Influencing Surgical Mortality and the Reversal of Hartmann's Procedure Chen, C.-W.; Wu, C.-C.; Hsiao, C.-W. (Taipei); Lai, H.-J. (Hualien); Lee, T.-Y.; Jao, S.-W. (Taipei)

Case Reports

155 Actinomycosis of the Rectum: Imitation of a Malignant Neoplasia - Case Report of a Laparoscopic Rectum Resection Bärlehner, E. (Berlin)

159 Diagnostic and Therapy of the IntraductalPapillary Mucinous Neoplasm of the Pancreas a Case Report

Braun, K.-P.; Gastinger, I.; Kube, R.; May, M.; Theissig, F.; Ernst, H. (Cottbus)

163 Adenocarcinoma from Esophageal Clonic Interposition Lin, T.-C.; Lin, Y.-C. (Taipei)

2171 Isolated Myeloid Sarcoma of the Small Intestine in an Aleukemic Patient - Case Report and Review of the Literature Venizelos, I.D.; Frakandreas, G.; Tatsiou, Z.A.; Goulis, I. (Thessaloniki)

\section{Brunner's Gland Hyperplasia: A Rare Cause} for Gastric Outlet Obstruction Dang, S.; Atiq, M.; Cone, J.; Svoboda, P.; Ionita, M.; Olden, K.W.; Aduli, F. (Little Rock, AR) 
3243 Early Klebsiella pneumoniae Liver Abscesses Associated with Pylephlebitis Mimic Hepatocellular Carcinoma

Chien, C.-Y.; Shen, C.-H.; Lin, J.-C.; Hsieh, T.-Y. (Taipei)

3246 Successful Medical Treatment with Percutaneous Drainage of Splenic Abscesses: Case Report and Review of the Literature

Hsiao, P.-J.; Liu, W.-H.; Wang, C.-W.; Chang, F.-Y. (Taipei)

3259 Solitary Benign Schwannoma of the Psoas Muscle: A Case Report

Fu, C.-Y.; Lin, C.-H.; Yu, T.-C.; Lu, T.-C.; Hsieh, C.-B. (Taipei)

3252 A Metastatic Hepatocellular Carcinoma Presenting as Sister Mary Joseph's Nodule after Liver Transplantation

Fan, H.-L.; Yao, N.-H.; Yu, C.-Y. (Taipei); Hsieh, H.-F. (Taoyuan); Yu, J.-C.; Hsieh, C.-B. (Taipei)

4309 Ectopic Pancreatic Tissue within the Duodenal Wall Possible Additional Cause for Symptomatic Chronic Pancreatitis

Lemberg, C.; Schulz, H.-U. (Magdeburg); Kellner, U. (Minden); Lippert, H.; Meyer, F. (Magdeburg)

4313 Hemobilia after Percutaneous Liver Biopsy Presenting as Hematochezia: A Rare Complication of a Commonly Performed Procedure Dang, S; Neelima, V.; Atiq, M.; Olden, K.W.; Aduli, F. (Little Rock, AR)
Book Reviews

$\mathbf{1} 66, \mathbf{3} 255,4318$

Innovations

2176

News / Ticker

$169,2181,3261,4316$

Meetings and Conferences

1 72, 2 182, 3263,4323

4326 Author Index Vol. 24, 2008

4329 Subject Index Vol. 24, 2008 